\title{
Isolation and Molecular Characterization of Bovine Herpes Virus Type 1 from Upper Respiratory Tract of Bovines
}

\author{
Rakhi Gangil, Gurpreet Kaur, P.N. Dwivedi
}

10.18805/IJAR.B-4552

\begin{abstract}
Background: Bovine herpes virus type 1 (BoHV-1) the causative agent of Infectious bovine rhinotracheitis (IBR) is of great concern to dairy farmers and veterinarians due to great economic impact caused by the virus in terms of loss of production and abortion Therefore, the study was planned to detect the virus circulating in the bovine population of the region under study. This virus is an important pathogen of bovine respiratory diseases. The aim of the present study was to isolate the BoHV- 1 virus from the upper respiratory tract of bovines.

Methods: A total of 13 nasal swab samples were subjected to virus isolation in Madin Darby Bovine Kidney (MDBK) cells lines. A PCR assay was applied to confirm the BoHV-1 DNA by targeting gl glycoprotein gene in isolates.

Result: Total two IBR virus isolates were recovered from 13 nasal swab samples of bovines. Both isolates exhibited cytopathic effects i.e. clumping and rounding of cells. A 468 base pair of amplified product from both isolates confirmed the IBR virus in $\mathrm{gl}$ gene specific PCR for BoHV-1. This study concludes that IBR virus exists among cattle population of Punjab and it is present in the upper respiratory tract of infected animal and shed through respiratory route. The PCR detection assay for detection of BoHV-1 from nasal swab samples is considerably more sensitive than virus isolation.
\end{abstract}

Key words: Bovine, BoHV-1, Isolation, Upper respiratory tract, PCR.

\section{INTRODUCTION}

Infectious Bovine Rhinotracheitis (IBR) is caused by Bovine Herpesvirus -1 (BoHV-1) a member of the genus Varicellovirus in the sub family Alphaherpesvirinae which belongs to the family Herpesviridae (Murphy et al., 1999) and newly assigned order Herpesvirales (MacLachlan and Dubovi 2011). BoHV-1 is one of the most important pathogens of respiratory disease complex called shipping fever. IBR is an economically important viral disease of domestic and wild cattle. It has been described as an acute, contagious, febrile infection of cattle, characterized by an intense inflammation of the upper respiratory passages and trachea. It is accompanied by dyspnea, depression, nasal discharge and loss of condition. Besides respiratory infection, BoHV-1 is associated with ocular, reproduction, central nervous system, enteric, neonatal and dermal infections of cattle and other species (Ata et al., 2008). The disease has been reported not to be highly fatal but it causes considerable economic loss due to abortion, loss of body condition, reduction of milk yield, temporary failure of conceptions, secondary bacterial pneumonia and cost of treatments.

In India, the first case of IBR was reported by Mehrotra et al. (1976) by isolating the virus from keratoconjunctivitis form of the disease in an organized farm of Uttar Pradesh. Subsequently, isolation of virus from the cases of abortion in cows was also reported (Mehrotra, 1977). Serological investigations, thereafter, have indicated the prevalence of IBR infection in alarming proportion in most of the states of India (Patil et al., 2017). The disease was found to be more prevalent in exotic and crossbred cattle than in indigenous
Department of Veterinary Microbiology, Guru Angad Dev Veterinary and Animal Science University, Ludhiana-141004, Punjab, India.

Corresponding Author: Rakhi Gangil, Department of Veterinary Microbiology, College of Veterinary Science and Animal Husbandry, Mhow-453 446, Madhya pardesh, India. Email: rgangil@gmail.com

How to cite this article: Gangil, R., Kaur, G. and Dwivedi, P.N. (2021). Isolation and Molecular Characterization of Bovine Herpes Virus Type 1 from Upper Respiratory Tract of Bovines. Indian Journal of Animal Research. DOI: 10.18805/IJAR.B-4552.

Submitted: 01-06-2021 Accepted: 10-08-2021 Online: 08-09-2021

breeds. The disease has been recorded from Kerala (Sulochana et al., 1982), Gujarat (Singh et al., 1983), Tamil Nadu (Manickam and Mohan, 1987), Orissa (Mishra and Mishra, 1987) Andhra Pradesh (Satyanarayana and Suri Babu, 1987), Karnataka (Mohankumar et al., 1994), Uttar Pradesh (Pandey et al., 2000) and West Bengal (Ganguly et al., 2008).

BoHV-1 infection generally occurs above 6 month of age when maternal immunity has waned (Bennet and ljpelaar, 2003). The virus is excreted through various routes viz., nasal and ocular secretions, placenta of aborted animals and most importantly through semen (Jithin et al. 2019). Further the BoHV-1 virus remains latent in the neurons of trigeminal ganglia in case of respiratory infection and sacral ganglion after genital infection for the entire life in the host (OIE, 2008). Any stressful condition such as parturition, transportation, high ambient temperature (in case of pure and crossbreeds), high milk yield and artificial stress cause reactivation of the latent virus and consequently intermittent 
shedding of virus into the environment which is a potent source of infection to other healthy animal (Radostits et al. 2000 and OIE, 2008).

Current methods of BoHV-1 detection used in diagnostic virology laboratories include virus isolation, ELISA and PCR. Diagnosis of BoHV-1 virus can be difficult due to latency of virus in ganglion. Various PCR assays for the detection of BHV-1 have been described (Kibenge et al., 1994 and Vilcek et al., 1994). Many researchers have been made the isolation of IBR virus from different areas (Rangnatha et al., 2013, Patil et al., 2016, Ravishankar et al., 2012 and Surendra et al., 2015).

In India no routine vaccination against Infectious Bovine Rhinotracheitis (Bovine Herpes virus type-1) is undertaken in cattle till now. Present work has been aimed to isolate the BoHV-1 virus from the upper respiratory tract of bovines thereby any BoHV-1 isolate from cattle would be the field strain virus.

\section{MATERIALS AND MeTHODS Collection of samples}

A total of 100 nasal swab samples were collected from all ages of cattle and buffaloes exhibiting clinical signs of respiratory infections viz., coughing, depression, fever, nasal and ocular discharge and anorexia during the period from November 2016 to March 2018 from different Gaushalas in and around Ludhiana and Teaching Veterinary Clinical Complex, College of veterinary Science, Guru Angad Dev Veterinary Science University Ludhiana, Punjab. Samples were collected with sterile swab in phosphate buffer saline (PBS) in a $15 \mathrm{ml}$ sterile centrifuge tube. All the samples were screened by PCR for BoHV-1. Among them only three nasal swab samples were found positive. In this study, all three BoHV-1 PCR positive samples including 10 other randomly selected samples were used for virus isolation in MDBK cell lines.

\section{Preparation of virus inoculum/ sample processing}

Two $\mathrm{ml}$ of nasal swab samples were centrifuged at $825 \mathrm{x} \mathrm{g}$ for 15 minutes to collect the supernatant. Then 15 il of antibiotic antimycotic solution (100X, Himedia) was added to the supernatant and incubated at $37^{\circ} \mathrm{C}$ for 30 minutes. The processed samples were stored at $-20^{\circ} \mathrm{C}$ to be used further for virus isolation.

\section{Cell lines}

MDBK cell line was procured from the School of Animal Biotechnology, GADVASU, Ludhiana and stored in liquid nitrogen $\left(\mathrm{LN}_{2}\right)$ till further use.

\section{Reference virus}

Standard reference virus was procured from the School of Animal Biotechnology, GADVASU, Ludhiana.

\section{Isolation of BoHV-1 in cell culture}

MDBK cells were distributed in 12 well cell culture plate to grow for $70 \%$ confluence. The growth media was discarded and washed three times with maintenance media. Processed samples (virus inoculum) were filtered through $0.22 \mu \mathrm{m}$ filters and cells were infected with $100 \mu$ l filtrate of inoculum. For each plate, cell control and virus control were included. The plates were kept at $37^{\circ} \mathrm{C}$ in $\mathrm{CO}_{2}$ incubator for one and half hour for viral adsorption. After adsorption, the cells were washed with DMEM to remove unbound virus particles and replaced with $500 \mu \mathrm{l}$ of maintenance media (containing $2 \%$ FBS). The infected cells were incubated at $37^{\circ} \mathrm{C}$ in an incubator with $5 \% \mathrm{CO}_{2}$. Daily observation was carried out at $24 \mathrm{hr}, 48 \mathrm{hr}, 72 \mathrm{hr}, 96 \mathrm{hr}$ and $120 \mathrm{hr}$ post inoculation for development of cytopathic effect (CPE). CPE was characterized by grape like cluster of rounded cells in the monolayer. After 5 days of incubation, whether CPE has been observed or not, plates were subjected to alternative freezing and thawing for three times and then the cell culture supernatant was harvested aseptically. The harvested cell culture supernatants were stored at $-80^{\circ} \mathrm{C}$ for virus identification. The samples that did not exhibit CPE in first passage were further subjected to $2^{\text {nd }}, 3^{\text {rd }}$ upto $5^{\text {th }}$ passage. In case of no CPE observed after fifth passage, the sample was regarded as negative for BoHV-1.

\section{DNA extraction}

The DNA was extracted from the cell culture supernatant and reference virus using phenol chloroform DNA extraction method (Sambrook and Russell, 2001). The DNA was eluted in $30 \mu \mathrm{l}$ of NFW and stored at $-20^{\circ} \mathrm{C}$ till further use.

\section{Polymerase Chain Reaction}

For identification of virus, PCR amplification was carried out for conserved sequence of glycoprotein I $(g l)$ gene using specific published primers (Vilcek et al., 1994). The primers sequence used were g/ F (624-CACGGACCTGGT GGACAAGAAG-645) and $g /$ R (1070-CTACCGTCACGTGA GTGGTACG-1091) for amplification of 468 bp product. The PCR reaction mixture contained $2.5 \mu$ of $10 X$ PCR buffer (with $15 \mathrm{mM} \mathrm{MgCl}_{2}$ ), $1.0 \mu \mathrm{l}$ of forward and reverse primer $(20 \mathrm{pm} / \mu \mathrm{l})$ each, 1.0 ì of dNTPs mix (10mM each), $0.2 \mu \mathrm{l}$ Taq DNA polymerase (5 units/ $\mu \mathrm{l}), 10 \mu \mathrm{l}$ of extracted DNA (150 - 400ng) and the reaction was made up to $25 \mu \mathrm{l}$ using nuclease free water. The thermocycler (BioRad, Thailand) conditions were initial denaturation at $95^{\circ} \mathrm{C}$ for $3 \mathrm{~min}, 35$ cycles of denaturation at $95^{\circ} \mathrm{C}$ for $1 \mathrm{~min}$, annealing at $51.8^{\circ} \mathrm{C}$ for $1 \mathrm{~min}$, extension at $75^{\circ} \mathrm{C}$ for $1 \mathrm{~min}$ and final extension at $75^{\circ} \mathrm{C}$ for $10 \mathrm{~min}$. The negative control consisted of sterile water instead of DNA template while positive control consisted of DNA extracted from reference virus. After amplification the reaction mixture, it was electrophoresed in $1.5 \%$ agarose gel and stained with ethidium bromide. The amplified product was visualized as a single compact band of $468 \mathrm{bp}$ under in gel documentation system (Syngene, USA).

\section{RESULTS AND DISCUSSION}

BoHV-1 is the causative agent of IBR which is important emerging disease of bovines distributed worldwide including 
India (Gibbs and Rweyemamu, 1977; Kilari et al., 2000 and Dhand et al., 2002). This virus has been associated with a variety of clinical disease manifestations including rhinotracheitis, vulvovagititis, balanoposthitis, abortion, conjunctivitis and generalized systemic infections in newborn calves (Gibbs and Rweyemamu, 1977; Rola et al., 2005). Naturally occurring BoHV-1 in respiratory form usually go unnoticed and does not cause high mortality amongst affected animals, but persistence of the virus causes the economic losses due to reduced production, impaired work ability, abortion etc. (Jones and Choudhary, 2007; Ravishankar et al., 2012). As virus remains in carrier stage, serum based test are not suitable for accurate diagnosis of BoHV-1 infection. Diagnosis of IBR virus is usually based on ELISA, PCR and virus isolation test. Virus isolation is known as a gold standard for diagnosis of IBR infection. Present study was aimed to isolate the virus from nasal swab samples. However, the report of isolation of virus in pneumonic cases of bovine is scare in India except few solitary reports of isolation in nasal secretion (Saha et al. 2010 and Patil et al., 2016).

In present study, two virus isolates were recovered from 13 nasal swab samples. Cytopathic effect in the form of rounding and clumping of cells has been described as a characteristic phenomenon of BoHV-1 by Mehrotra (1977) and Suresh et al. (1993). It was observed that virus isolates did not produce CPE till second passage in any sample. Both the samples showed characteristic CPE in the third passage. Although, one sample $(\mathrm{N}-1)$ exhibited extensive CPE after $48 \mathrm{hrs}$ in the form of clumping of cells like bunches of grapes. In another sample (N-2), clumping of cells was seen after 72 hrs of third passage (Figure 1). Remaining samples did not exhibit any CPE even after fifth passage.

Growth of virus in cell culture confirmed by bunch of grape-like clustering and rounding of cell, which was in correlation with previous BoHV-1 isolation studies (Das et al., 2014). Similarly, Saha et al. (2010) and Ranganatha et al. (2013) attempted IBR virus isolation from nasal swab samples in MDBK cell lines. In their study, only one and three isolates were obtained from 65 and 40 nasal swabs respectively. In this study, lesser number of isolates was recovered from nasal swab samples; it might be due to low concentration of virus excreted through respiratory route. In this study CPE was observed within 48-72 hrs of third passage. Mohankumar et al. (1994) isolated the virus from nasal and conjunctival swabs and a virus isolate was recovered after five serial passages in MDBK cells. Dhami (2001) also isolated the virus in MDBK cells and CPE was visible by fifth passage level.

DNA was isolated from suspected BoHV-1 isolates having CPE and PCR was performed using a gl gene specific primer. In PCR 468 bp product was amplified from both virus isolates which confirmed the presence of IBR virus (BoHV-1) in nasal swab samples (Fig 2). Both isolates were obtained from adult female crossbred cattle. Out of three PCR positive samples only two samples could be detected as positive virus for isolation. In PCR we detect the nucleic acid and can be detected in sample even if the virus in the sample is not fine. But in isolation of virus from sample, live virus is needed. The cell culture was not done simultaneously along with the conducting PCR on the samples and the samplers were stored for further isolation of virus. There is quite possibility that the virus was not live in one of the PCR positive sample which could not be isolated. The results in our study show that the PCR detection in nasal swab samples is considerably more sensitive than virus isolation. The reason behind could be the fact that PCR detects and amplify the dead virus particles where as virus isolation cannot. Engelenburg et al. (1995) compared PCR with routine virus isolation methods and reported that $P C R$

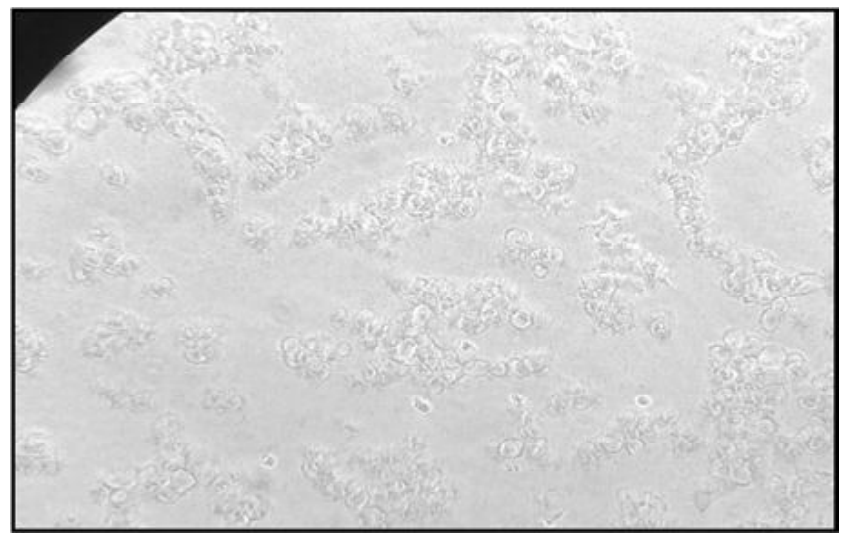

Fig 1: Clumping of MDBK cells like "bunches of grapes" $72 \mathrm{hrs}$ of post infection at $10 \mathrm{X}$.

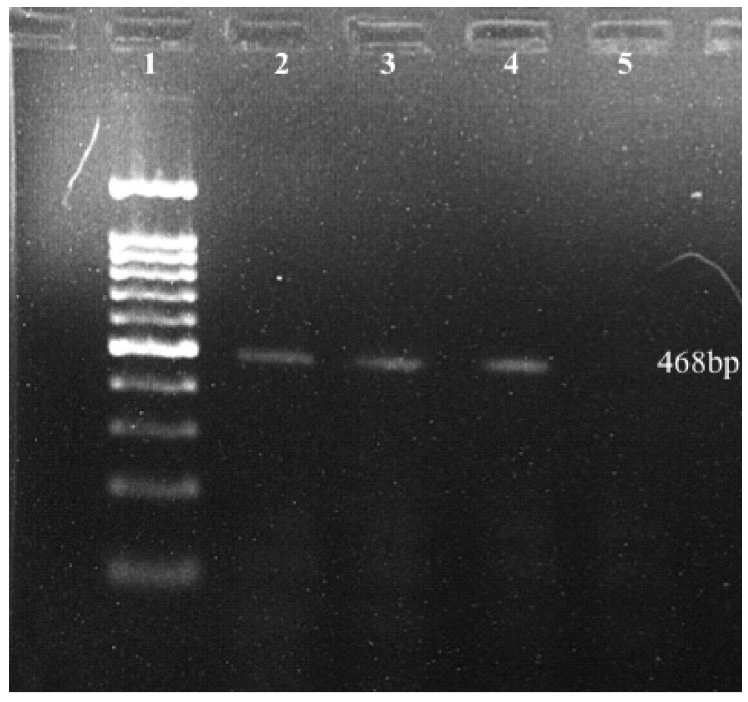

Fig 2: PCR amplification of gl gene of isolates of IBR virus. Lane 1 - DNA ladder.

Lane 2 - Positive Control.

Lane 3 - Cell culture isolate of nasal swab sample $(\mathrm{N}-1)$.

Lane 4 - Cell culture isolate of nasal swab sample (N-2).

Lane 5 - Negative control. 
was 2 to 100 fold more sensitive, moreover results of PCR was available within a day in comparison to the virus isolation which takes many more days and many more passages and at least 7 days to complete. PCR is an invaluable tool for fast and sensitive detection of BoHV-1 in biological and clinical specimens (Mahajan et al., 2013). Deka et al. (2005) also suggested that PCR is more sensitive method for BoHV-1 screening in Bulls. Both the isolates were confirmed by 468 bp amplified product in gl gene specific PCR. Many researchers used amplification of $\mathrm{gl}$ gene of BoHV-1 for diagnosis and understanding the molecular epidemiology and disease distribution of disease in India and worldwide (Nisavic et al., 2018; Hashemzehi et al., 2017, Deka et al., 2005 and Singh et al., 2013).

Both isolates were from adult female crossbred cattle. More susceptibility of these cattle might be due to less adaptation of crossbred cattle in Indian climate and high production stress in female. Moreover it is known that semen is the main source of infection. Above findings are according to Rajesh et al. (2003) who reported higher prevalence of IBR in above three years of age cattle population of Kerala. Further they revealed that risk of infection is more in animals that had a parity of two of more and crossbred of Holstein Friesian. The increase in the incidence of IBR infection with age could be due to the fact that as animals grow older, they are more likely to be exposed to the virus since they are more likely to come into contact with other animals which have recovered from the disease but remains carrier. In present scenario, animal husbandry development is directed towards the rearing of crossbred cattle to get more production in tropical and subtropical countries and crossbred animals are more susceptible to heat stress. The virus remain latent for lifelong in BoHV-1 infected animal. The virus excreted through secretions (nasal ocular and vaginal) in any stress condition and imposes the threat of virus dissemination (Pistl et al., 2003).

The low recovery of IBR virus from nasal secretion was due to the fact that BoHV-1 might not be the incriminate cause of respiratory problems of sampled animals. Sampling for virus isolation should be done in early course of the disease because virus shedding occurs during the early acute phase of the disease (between third to sixth days), when the discharge is serous rather than mucoprulent (OIE 2008).

\section{CONCLUSION}

This study concludes that IBR virus exists among cattle population of Punjab. The virus is present in the upper respiratory tract of infected animal and shedding the virus through respiratory route. Several seroprevalence reports demonstrate that IBR is now established and endemic in India. Further studies with isolation and molecular characterization of viruses collected from different geographical areas will contribute to understand the epidemiology and development of diagnostic and effective vaccine against IBR.

\section{ACKNOWLEDGEMENT}

The authors are thankful to Director of Research and Head of the Department of Veterinary Microbiology for providing the necessary funds and facilities to conduct the research.

\section{REFERENCES}

Ata, A., Kocamuftuoglu, M., Hasircioglu, S. and Kale, M. (2008). Investigation of bovine herpesvirus-1 (BHV-1) infection in relation to fertility in repeat breeder cows. Proceeding of the $16^{\text {th }}$ congress of the Mediterranian Federation for Health and Production of Ruminants, Croatia. 63-69. April 26, Zadar.

Bennett, R. and ljpelaar, J. (2003). Economic Assessment of Livestock Diseases in Great Britain, Final Report of DEFRA, the University of Reading.

Das, P., Mohanty, N.N, Ranganatha, S., Ranabijuli, S., Sarangi, L.N, Panda, H.K.A. (2014). Comparative evaluation of avidin-biotin ELISA and micro SNT for detection of antibodies to infectious bovine rhinotracheitis in cattle population of Odisha, India. Veterinary World. 7: 548-552.

Deka, D., Ramneek., Maiti, N.K. and Oberoi, M.S. (2005). Detection of bovine herpesvirus-1infection in breeding bull semen by virus isolation and polymerase chain reaction. Revenue Scientifique Technique Office International Epizootics. 24: 1085-94.

Dhami, J.S. (2001). Studies on diagnosis of bovine herpesvirus-1 infections in cattle and biffaloes. M.V.Sc. Thesis, Punjab Agricultural University, Ludhiana, India.

Dhand, N.K., Singh, G, Sharma, D.R. and Sandhu, K.S. (2002). Seroprevalence of infectious bovine rhinotracheitis in Punjab. Indian Veterinary Journal. 72: 850-852.

Engelenburg, F.A., Van Schie, F.W., Rijsewijk, F.A.M. and Van Oirschot, J.T. (1995). Excretion of bovine herpesvirus-1 in semen is detected much longer by PCR than by virus isolation. Journal of Clinical Microbiology. 33: 308-18.

Ganguly, S., Mukhopadhya, S.K. and Paul, I. (2008). Studies on seroprevalence of infectious bovine rhinotracheitis in cattle population of West Bengal. Indian Journal Comparative Microbiology Immunology and Infectious Disease. 29(1-2): 12-16.

Gibbs, E.P. and Rweyemamu, M.M. (1977). Bovine herpesviruses. Part I, Commonwealth Bureau of Animal Health. The Veterinary Bulletin. 47: 317-43.

Hashemzehi, R., Kilic, A., Akbarpour, A., Mahmoudi, E. and Arshi, A. (2017) Molecular study for bovine herpes virus type 1 detection in Iranian cattle. International Journal of Animal Research. 1: 7.

Jithin, P.M., Surya, S., Mani, B.K., Simon, S., Reji, R.M., Bosewell, A. and Mini, M. (2019). Serologica and molecular detection of Bovine Herpes Virus 1 infection in cattle by enzyme linked immunosorbent assay and polymerase chain reaction. Indian Journal of Animal Research. 53: 1661-1665.

Jones, C. and Chowdhary, S. (2007). A review of the biology of bovine herpesvirus type-1 (BHV-1), its role as a cofactor in the bovine respiratory disaese complex and development of improved vaccines. Animal Health Research Review 8: 187-205. 
Kibenge, F.S., Harris, L.M., Mckenna, P.K., Wadowska, D. and Yason, C.V. (1994). Amplification of strains of bovine herpesvirus 1 by use of polymerase chain reaction with primers in the thymidine kinase region. American Journal of Veterinary Research. 55: 1206-12.

Kilari, S., Singh, S.N., Buche, A.V., Sawarkar, S. and Ghosh, S. (2000) Evaluation of immunogenecity of infectious bovine rhinotracheitis vaccine in Indian tropical climate. Indian Veterinary Journal. 77, 185- 188.

MacLachlan, N.J. and Dubovi, E.J. (2011). Fenner's Veterinary Virlogy. $4^{\text {th }}$ Edn. Academic Press, London. P: 180.

Mahajan, V., Banga H.S., Deka, D., Filia, G. and Gupta, A. (2013). Comparison of diagnostic tests for diagnosis of infectious bovine rhinotracheitis in natural cases of bovine abortion. Journal of Comparative Pathology. 149(4): 391-401.

Manickam, R. and Mohan, M. (1987). Seroepidemiological studies on Infectious bovinerhinotracheitis (IBR) viral abortions in cows. Indian Journal of Animal Science. 57: 959-62.

Mehrotra, M.L., Rajya, B.S. and Kumar, S. (1976). Infectious bovine rhinotracheitis (IBR) keratoconjunctivities in calves. Indian Journal Veterinary Pathology. 1: 70-73.

Mehrotra, M.L. (1977). Isolation and characterization of infectious bovine rhinotracheitis/ infectious pustular vulvovaginitis (IBR/ IPV) virus associated with abortion in cow. Indian Journal of Animal Science. 49: 346-49.

Mishra, P.K. and Mishra, A. (1987). Infectious bovine rhinotracheitis virus infection and infertility in cows, heifers and bulls. SO: Indian Journal of Animal Sciences. 57: 267-71.

Mohankumar, K.M., Rajasekhar, M. and Krishnappa, G. (1994). Isolation of infectious bovine rhinotracheitis virus in Karnatak. Indian Veterinary Journal. 71(2): 109-113.

Murphy, F.A., Gibbs, E.P.J., Horzinek, M.C., Studdert M.J. (1999). Paramyxoviridae. In: Veterinary Virology, $3^{\text {rd }}$ Edn., Academic press, USA, p. 423.

Nisavic, J., Knezevic, A., Stanojevic, M., Milic, N. and Radalj, A. (2018). Molecular detection of Bovineherpes virus-1 (BoHV-1) in cattle in Serbia. Revue De Medicine Veterinaire. 7: $180-84$.

OIE (2008). Infectious bovine rhinotracheitis/ pustular vulva infectious vaginitis. Manual of Diagnostic Tests and Vaccines for Terrestrial Animals. Chapter 2.4.13, pp. 752-67.

Pandey, A.B., Mehrotra, M.L., Verma, R.P. and Pati, U.S. (2000). Investigation of an outbreakof infectious pustular balanoposthitis in breeding bulls. Indian Journal of Veterinary Research. 9: 27-37.

Patil, S.S., Prajapati, A., Hemadri D., Suresh, K.P., Desai, G.S., Reddy, G.B., Chandranaik. B.M., Ranganatha, S. and Rahman, H. (2016). Phylogenetioc analysis of glycoprotein $B$ gene sequences of bovine herpesvirus 1 isolates from india reveals the predomionance of subtype 1.1. Veterinary World. 9(12): 1364-69.

Patil, S.S., Prajapati, A., Krishnamoorthy, P., Desai, G.S., Reddy, G.B., Suresh, K.P. and Rahman, H. (2017). Seroprevalence of infectious bovine rhinotracheitis in organized dairy farms of India. Indian Journal of Animal Research. 51: 151-154.

Pistl, J., Bobakova, M., Mudron, P. and Pilipcinec, E. (2003). Infectious bovine rhinotracheitis- the tropical problem. Slovensky Veterinarsky Casopis. 28: 24-28.
Radostits, O.M., Gay, C.C., Blood, D.C. and Hinchcliff, K.W. (2000). Infectious bovine rhinotracheitis (IBR, Red nose), bovine herpesvirus-1 (BHV-1) infection. In: Veterinary Medicine. [Radostits, Gay, Blood, Hinchcliff (Eds.)]. WB Saunders Co., London, PP. 1173-84.

Rajesh, J.B., Tresamol, P.V. and Saseendranath, M.R. (2003). Seroprevalence of infectious bovine rhinotracheitis in cattle population of kerala. Indian Veterinary Journal. 80: 393-396.

Ranganatha, S., Rathnamma, D., Patil, S.S, Chandranaik, B.M., Isloor, S., Veeregowda, B.M., Narayanabhat, M. and Srikala. (2013). Isolation and molecular characterization of Bovine Herpes Virus-1 by Polymerase Chain Reaction. Indian Journal of Animal Research. 47(4): 340-43.

Ravishankar, C., Nandi, S., Chander V and Mohapatra T.K. (2012). Glycoprotein C Gene Based Molecular Subtyping of a Bovine Herpesvirus-1 Isolate from Uttar Pradesh, India. Indian Journal of Virology. 23: 402-06.

Rola, J., Larska, M. and Polak, M.P. (2005). Detection of bovine herpesvirus-1 from an outbreak of infectious bovine rhinotracheitis. Bulletin of Veterinary Institute in Pulawy. 49: 267-71.

Saha, T., Guha, C., Chakraborty, D., Pal, B. and Biswas, U. (2010). Isolation and Characterization of BoHV-1 from Cattle in West Bengal, India. Iranian Journal of Veterinary Science and Technology. 2(1): 1-8.

Sambrook, J. and Russell, D.W. (2001). Molecular Cloning: A Laboratory Mannual. $3^{\text {rd }}$ Edn. Cold Spring Harbor Laboratory Press, New York.

Satyanarayana, K. and Suri Babu, T. (1987). Serological survey of bovine herpes virus-1 (BHV-1), infection in bovines in Andhra Pradesh. Indian Journal of Animal Science. 57: 499-502.

Singh, B.K., Ramakant and Tongaonkar S.S. (1983). Adaptation of Infectious bovinerhinotracheitis virus in Madin - Darby bovine kidney cell line and testing of buffalo sera for neutralizing antibodies. Indian Journal of Comparative Microbiology Immunology and Infectious Disease. 4: 6-8.

Singh, R., Verma, A.K., Sharma, B. and Yadav, S.K. (2013). Detection of bovine herpes virus-1 (BHV-1) infection in cattle by antigen detection ELISA and multiplex PCR. Advances in Animal and Veterinary Science. 1(3S): 12-16.

Sulochana, S, Pillai, R.M., Nair, G.K. and Abdulla, P.K.R. (1982). Serological survey on the occurrence of infectious bovine rhinotracheitis in Kerala. Indian Journal of Comparative Microbiology Immunolology and Infectious Disease. 3: 7-11.

Surendra, K.S.N, Rana, S.K., Subramanian, B.M., Reddy, R.V.C., Sharma, G.K., Srinivasan, V.A. (2015). Phylogenetic analysis of bovine herpes virus isolate of India. Advances in Animal and Veterinary Science. 3: 451-460.

Suresh, K.B., Kumanan, K., Dhinakaran, M., Padmanabhan, V.D. and Raghavan, N. (1993). Growth characteristics of bovine herpesvirus-1 in MDBK cell line. Indian Veterinary Journal. 70: 204-06.

Vilcek, S., Nettleton, P.F. and Herring, A.J. (1994). Rapid detection chain reaction. Veterinary Microbiology. 42: 53-64. 